\title{
Типи експансії соціальних платформ в українському ландшафті
}

\author{
М. Ю. Наумова
}

Інститут соціології Національної академії наук України

Corresponding author. E-mail: martanaumova1971@gmail.com

Paper received 05.07.20; Accepted for publication 28.07.20.

\section{https://doi.org/10.31174/SEND-HS2020-237VIII41-14}

Анотація. Соціальні мережі стали сьогодні центральним елементом дизайну медійного простору і панівним способом переживання повсякденності. На грунті даних двох хвиль моніторингу «Українське суспільство» Інституту соціології НАН України -- 2017 та 2019 років -- в статті розглядається динаміка преференцій українців щодо основних платформ та активностей в соціальних медіа. В матеріалі також презентована сегментація користувачів соціальних медіа за преференціями щодо їх використання, та соціальнодемографічний профіль кожної категорії юзерів.

Ключові слова: соиіальні медіа, соиіальні мережі, опlinе практики, юзер-генерований контент, мережево-цифрова культура.

Вступ. Починаючи з 1990-х рр. метафора мережі займає центральне місце в описах нової соціальної онтології. Вона відбиває не тільки засадничі принципи нових цифрових комунікаційних систем - горизонтальну, багатовузлову, динамічну і нестійку зв'язаність, але й фундаментальні зміни у соціальних і культурних порядках. Мова йде про конкурентні стратегії і форми організації соціальної взаємодії: децентралізацію, гнучкість, відхід від ієрархій, індивідуалізацію тощо. [5] 3 розвитком глобальних мультимедійних систем і масового доступу до Інтернет, мережеві теорії, які фокусуються, за Кастельсом, на головному елементі морфології сучасного суспільства, починають продукувати власні моделі соціальної реальності в категоріях вузлів та потоків, народження, затвердіння і вмирання мереж та перманентного випробування їх сил, -- змаганнях за залучення актантів (Б. Латур).

Можливо, мережевим підходам можна дорікати за концептуальну розпливчастість та слабку евристику, коли мова йде про їх претензії на загально соціологічні концептуалізації. Але вони релевантні для дослідження феноменів безпосередньо породжених комунікаційною революцією з їх стохастичістю, нестабільністю та нелінійною структурною динамікою. Наприклад, таких, як соціальні медіа. Соціальні медіа - останні і найкрупніші еволюційні форми інтернету [1] - стали не просто засобом комунікації з глобальними амбіціями, а планетарною інфраструктурою, 3 таким рівнем проникнення i динамікою, що іï соціальні і культурні імплікації все важче адекватно осмислити.

Короткий огляд публікацій по темі. Хоча у вітчизняному соціологічному дискурсі невпинно зростає інтерес до «цифрової соціальності», більшість рефлексій носить загальнотеоретичний характер (Н. Костенко, Л. Стародубцева, Г. Почепцов інші). Це пов'язано з обмеженими можливостями науковців у реалізації емпіричних соціологічних досліджень.

Мета. Стаття створена на грунті даних двох хвиль моніторингового дослідження Інституту соціології НАН України «Українське суспільство» (2017 та 2019 років) і має на меті простежити динаміку преференцій українців щодо основних платформ та активностей в соціальних медіа та презентувати сегменти користувачів залежно від їх типових мережевих практик.

Виклад основного матеріалу. За даними моніторингу Інституту соціології частка користувачів соціальних мереж серед дорослих українців (18+) збільшилася за два роки на 27\% - з 57,5\% у 2017 році до 72,9\% у 2019 році. Фактично користування інтернет стає синонімом залученості й до сервісів соціальних медіа. $92.7 \%$ серед тих, хто має доступ до мережі має акаунт хоча б на одній соціальній платформі. Очевидно, що кількість активних юзерів соціальних мереж є суттєво нижчою. Так, за даними We Are Social та Hootsuite [2] частка активно залучених користувачів (користуються хоча б один раз на місяць) складає 39\% від всього населення України. Хоча це один з найнижчих показників серед Свропейських країн ${ }^{1}$, динаміка кількості інтернет юзерів і користувачів соціальними медіа цілком відповідає загальносвітовим трендам $[3,5]$. Мова йде про збільшення інтернетпенетрації, зростання аудиторії соціальних мереж, а також, про залучення до цифрової культури більш широкого кола маргінальних прошарків, тобто про пом'якшення цифрової нерівності (рис.1).

Останній тренд посилює поширення доступних мобільних пристроїв - стільникових телефонів, смартфонів, планшетів - які, завдяки спрощенню інтерфейсів і зменшенню самих гаджетів, забезпечують простий і дешевий доступ до мережі і соціальних платформ у будь якій локації [7]. Зростання кількості користувачів, чий доступ до інтернету опосередковують поряд 3 традиційними комп'ютерами і мобільні пристрої спостерігається серед усіх соціальних категорій, але найбільш вражаючою $є$ «мобілізація» старших вікових груп. У 2017 році доступ до інтернету через мобільний пристрій мали лише 17.4\% українців у віці старше за 50 років, а в 2019 році ця частка зросла в тричі (48.1\%) і становить майже половину цієї вікової групи. Цілком передбачуваним є той факт, що найбільша частка юзерів мобільних гаджетів серед молоді 18-29 років. Зараз вона складає майже три чверті (72,8\%), а два роки тому у 2017 році - 58,4\%. Серед студентів ця частка складає $93,6 \%$.

За останні два роки спостерігається збільшення кількості користувачів мобільними пристроями і серед мешканців села $344,8 \%$ у 2017 році до $60.1 \%$. Зросла частка користувачів смартфонами та планшетами серед категорії населення 3 доходом нижче за середній (з 38,6\% у 2017 році до $55.2 \%$ у 2019 році). В цілому це втішний тренд, адже доступ до інтернету та соціальних медіа 3

\footnotetext{
${ }^{1}$ Україна за цим критерієм обходить лише Молдову (30\%), має однаковий рівень активної пенетрацї соціальних медіа з Білоруссю та Косово (по 40\% відповідно) і суттєво поступається лідерам, наприклад, Данії, Швеції (72\%). Рівень в Німеччині складає 46\%. У Польщі $-47 \%$
} 
більш високою юзабіліті, це потужний інструмент соціальної інклюзії та подолання цифрової дискримінації маргінальних та вразливих прошарків.

Треба сказати, що поряд зі збільшенням частки інтернет-юзерів, які користуються мережею за допомогою мобільних пристроїв кількість, тих, хто залучає стаціо- нарні комп'ютери неухильно зменшується. За даними моніторингу Інституту соціології частка тих, хто користується для входу в інтернет лише стаціонарними комп'ютерами складала в 2017 році 58,7\%, а в 2019 на $20 \%$ менше (38.3\%).

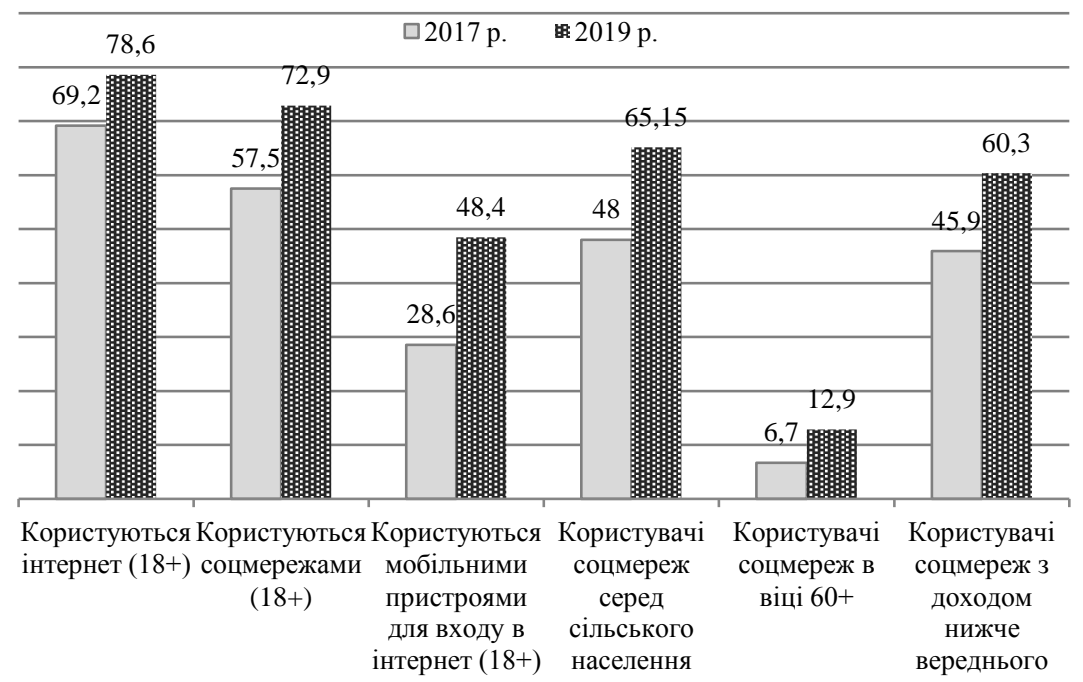

Рисунок 1. Динаміка інтернет-аудиторії і користувачів соціальних медіа (За даними моніторингу IC НАН України, 2017,2019, \%)

Середня кількість сервісів соціальних медіа, якими користуються українці також збільшилась і складає сьогодні 2.4, а два роки тому дорівнювала 2.0 акаунтам. Якщо у 2017 році більше третини користувачів мали акаунт лише на одній платформі (37,3\%), то зараз ця частка складає лише 22,5\%. Проте кількість аудиторії соцмереж, яка використовує три і більше сервісів зросла з $29,1 \%$ до $44,7 \%$.

Серед найпопулярніших сьогодні в Україні соціальних платформ -- Facebook та YouTube (58\% та 48,7\% користувачів відповідно відносно дорослого населення 18+; та 79.5\% 66,9\% - серед користувачів соціальних медіа) (рuс. 2). Третьою за популярністю платформою є Instagram (30,1\% серед дорослих українців та 41,3\% серед юзерів соціальних сервісів). Всі ці мережі демонструють зростання кількості юзерів, на відміну від російських сервісів Вконтакті і Однокласники. Ще в травні 2017 року, за даними дослідницької компанії Gemius Україна [4], Вконтакті очолювала рейтинг найпопулярніших соціальних медіа серед українців. Моніторингове дослідження Інституту соціології, яке проводилося в липні 2017 року, через півтора місяця після підписання Президентом України наказу №133/2017, який забороняв інтернет-провайдерам надавати послуги 3 доступу до російських соцмереж, інтернет-порталу «Яндекс» i поштового сервісу Mail.ru, зафіксувало значне зниження активних користувачів сайтів. Блокування російських соцплатформ суттєво не вплинуло на структуру аудитоpiï, але сприяло росту кількості Facebook акаунтів, що вивело сервіс на першу сходинку. Істотно зросла й аудиторія Twitter та Instagram. Загальна тенденція зменшення українських користувачів Вконтакті та Однокласників, яка спостерігається з 2014 року у зв'язку з поширення у суспільстві антиросійських настроїв зберігається і досі. За два роки їх популярність впала майже вдвічі. Частка користувачів Вконтакті знизилась з 25,8\% до 13,9\%, Однокласників 3 21,7\% до 13,2\% серед всього населення. Серед користувачів соціальних медіа ці частки становлять відповідно 19\% і 18\%)

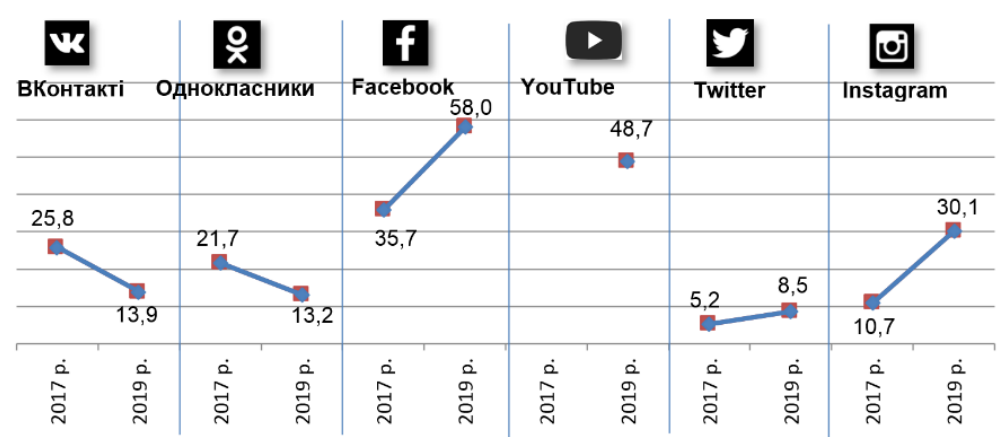

Рисунок 2. Динаміка охоплення української аудиторії популярними соціальними мережами (За даними моніторингу ІС НАН України, 2017, 2019, \%) 
Хоча апаратні та програмні елементи усіх платформ розвиваються досить стрімко, їх формати і особливості позиціювання не зазнали суттєвих трансформацій. Отже, i в структурі аудиторій найбільш популярних у Україні соціальних сервісів, важко знайти суттєві зрушення. Як і два роки тому Instagram, Вконтакті і Twitter, приваблюють переважно молодіжну аудиторію. Частка користувачів цих мереж у віці 18-39 років складає відповідно 64,5\%., 60,8\% і 59,7\%. Цілком передбачуваним є той факт, що саме серед поціновувачів Instagram та Twitter найбільша кількість тих, хто користується доступом до інтернету з мобільних пристроїв (77,5\% та 73,4\%). Однокласники залишаються найбільш «зрілим» сервісом: $59,9 \%$ складають юзери старші за 40 років. У порівнянні 3 іншими платформами тут переважають акаунти жінок $(67,1 \%)$, осіб з середньою спеціальною освітою $(45,6 \%)$ та низьким матеріальним статусом (48,5\%). А частка «мобільних» юзерів мережі серед користувачів Однокласників складає лише половину (51.1\%)

Не залежно від того, яким платформам віддають перевагу користувачі соціальних медіа, найчастіше їх використовують для приватної комунікації: більш ніж дві третини $(70,6 \%)$ регулярно відслідковують стрічку своїх друзів; кожен другий $(51,2 \%)$ спілкується 3 друзями та близькими. $46,9 \%$ використовує соціальні медіа для отримання новин зі стрічок різноманітних інформаційних ресурсів. Це дещо більше ніж у 2017 році (42.2\%; різниця статистично значуща на рівні 5\%). Майже третина юзерів (30,4\%) діляться посиланнями на новини i інформацію, яку вважають цікавими.

Заслуговує уваги той факт, що інтернет, як джерело новин про суспільно-політичні події в країні вперше зрівнявся з телебаченням. Хоча це стосується лише користувачів соціальних сервісів (72.9\% населення у віці $18+)$ і в цілому українці віддають перевагу ТВ контенту, очевидно, що цей тренд буде набирати обертів (рис. 3). Він зумовлений не тільки зручністю та можливістю персоналізації отримання новин через мобільний чи стаціонарний доступ до інтернету. Аудиторія все частіше звертається до альтернативних медіа 3 метою підвищити якість своєї обізнаності у суспільних справах, іншими словами, цікавиться діяльністю інститутів моніторної демократії (Дж. Кін) [6], які публічно висвітлюють і критикують дії влади.
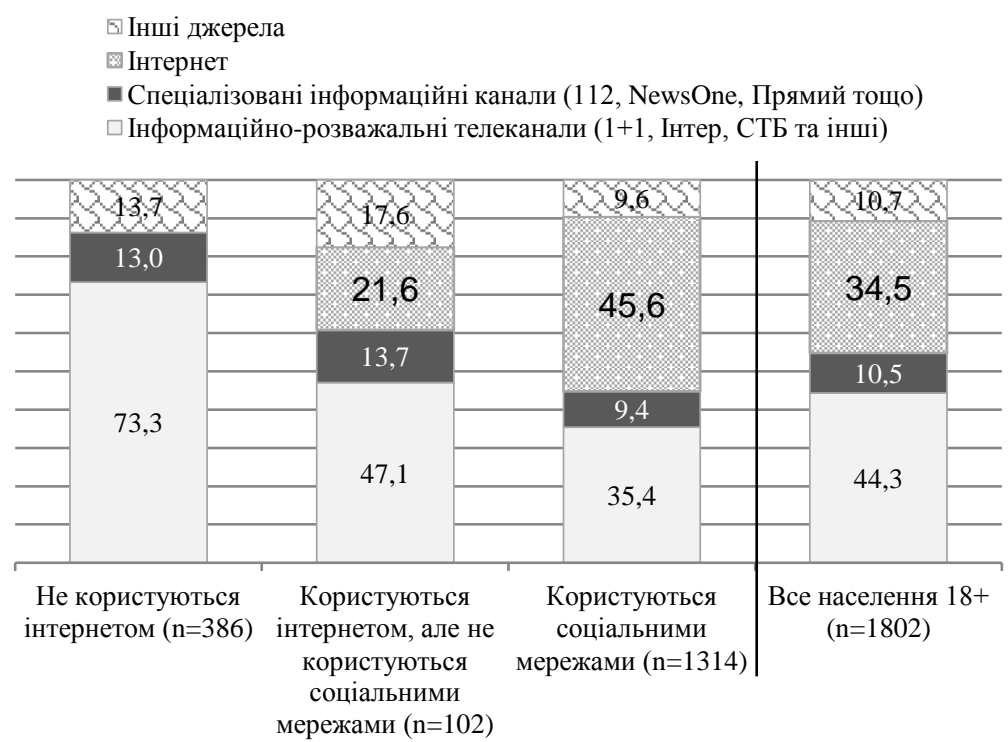

Рисунок 3. Джерела інформації про політичні і економічні події в Україні (За даними моніторингу ІС НАН Украӥни, 2019, \%)

Серед тенденцій на які слід звернути увагу - збільшення користувачів соціальних сервісів які відстежують стрічки популярних блогерів, політиків (8,7\% vs.20,4\%) та беруть участь у публічних обговореннях соціально значущих, резонансних подій (4,8\% vs.11,3\%). Кожен четвертий юзер (26.3\%) констатує, що час від часу бере участь у обговореннях в групах за інтересами. Авторитетні публічні фігури, які отримали повагу аудиторії завдяки висвітленню у своїх блогах порушення владою суспільних стандартів, стають своєрідними «необраними представниками» громадськості зі значно вищим рівнем довіри ніж у представників офіційного істеблішменту [6]. А соціальні платформи, забезпечуючи широкий доступ до такого контенту і інтерактивність, конструюють нетрадиційні моделі публічності, які набувають інших контурів і динаміки у порівнянні $з$ традиційними суспільними обговореннями.
На грунті проведеного кластерного аналізу ${ }^{2}$, серед користувачів соціальних медіа можна виділити чотири сегменти за типами превалюючих активностей. Для перших двох категорій головним мотивом користування соціальними платформами є спілкування: (1) «Близьке коло» (частка серед юзерів соціальних сервісів - 24\%); (2) «Публічна комунікація» (24\%); два інших сегменти орієнтовані переважно на отримання різноманітної інформації: (3) «Бути в курсі всього» $(17,4 \%)$; (4) «Новини» $(34,6 \%)$.

Серед сегменту «Близьке коло» головною мережевою практикою є спілкування з близькими (81,6\%), стеження за стрічкою друзів знайомих та друзів $(87,9 \%)$, а також розваги. Кожен другий представник сегменту грає в

\footnotetext{
${ }^{2}$ Метод K-means на основі збережених факторних навантажень після факторизації типових online-активностей користувачів соціальних медіа у мережі.
} 
ігри, пропоновані мережею (46,7\%) та ділиться різноманітним (49,2\%) розважальним контентом. Це фактично базовий функціонал з якого починався розвиток більшості соціальних платформ. Прихильників таких активностей трохи більше серед юзерів Однокласників та Вконтакті - частки «Близького кола» серед них складає відповідно $33,8 \%$ та 29,2\%.

Серед рівним за обсягом сегментом «Публічна комунікація» (24\% серед тих, хто має акаунти в соцмережах) також превалюють практики спілкування але в форматі публічних обговорень цікавих тем - від соціально значущих, резонансних подій до вузьких топіків у групах за інтересами (56.3\%). Такі юзери частіше обирають Facebook $(26,3 \%)$ та Twitter $(26,0 \%)$.

Два інших типи користувачів, які, на відміну від двох попередніх, орієнтовані не на спілкування, а на отримання інформації, разом складають трохи більше за половину аудиторії соціальних медіа: «Бути в курсі всього» $(17,4 \%)$ та «Новини» $(34,6 \%)$. Для «Бути в курсі всього» характерна певна інформаційна всеїдність - крім стрічок своїх друзів $(86,4 \%)$, вони відслідковують події у житті зірок $(86,4 \%)$, стежать за новинами акаунтів популярних блогерів $(70,2 \%)$ та інформаційних ресурсів (64,5\%). На відміну від інших сегментів, майже кожен третій представник «Бути в курсі всього» $(29,8 \%)$ - це молода людина у віці до 29 років. Найбільш популярними платформами тут $є$ Facebook $(85,5 \%)$, YouYube (78,9\%) Instagram (56,6\%). Проте, серед найбільшого сегменту «Новини» переважають юзери старших вікових категорій $(38,7 \%)$. Головний мотив користування соціальними сервісами для цієї групи полягає в споживанні новинного продукту з акаунтів різноманітних інформа- ційних ресурсів. Передбачуваними є їх уподобання відносно платформ: найпопулярнішими є Facebook $(67,9 \%)$ та YouTube $(64,2 \%)$.

Висновки. Соціально-демографічні профілі виокремлених категорій користувачів соціальних мереж не $\epsilon$ а ні унікальними, а ні чітко вираженими. Адже ідеологія i функціональні можливості «оргнетів» [1], пропонують майже весь репертуар соціальної інклюзії, симулюючи можливість формування значущих і тривалих зв'язків, приваблюючи юзерів не зважаючи на вік, гендер або статусні відмінності. Проте, превалюючи onlineактивності в межах кластерів тісно пов'язані із сенсом життя, що його артикулюють респонденти (рис. 4). Для сегменту «Близьке коло» найбільш значущими є родина, сімейний добробут, гідні статки. Серед користувачів, які належать до кластеру «Новини» більшу вагу мають суспільно-політичні цінності: соціально справедливість, громадська злагода, демократичний розвиток країни. Серед поціновувачів «Публічної комунікації» і тих, хто намагається «Бути в курсі всього» домінують індивідуалістичні цінності: самореалізація, успіх, професійні досягнення, намагання бути сучасним, прагнення внутрішньої гармонії та задоволення від життя.

Стрімке зростання пенетрації соціальних медіа, постійне розширення їх функціональних і апаратних можливостей, яке веде до консолідації на одній платформі усіх можливих приватних та публічних onlineактивностей, дозволяє говорити про черговий етап у розвитку технологічного режиму соціального - гегемонії соціальних платформ 3 їх специфічною ідеологією i економікою.

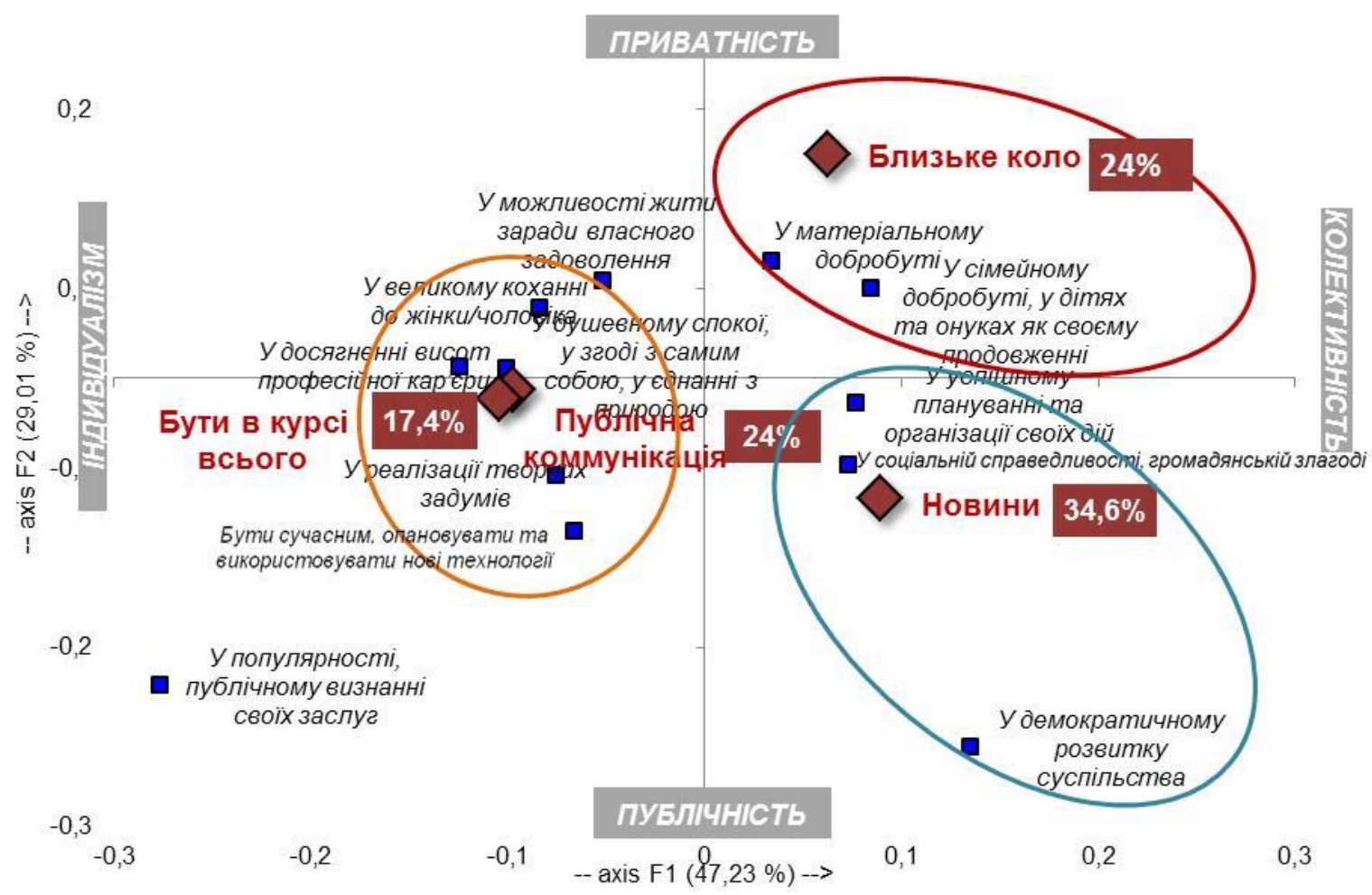

Рисунок 4. Сегменти за преференціями у мережевих активностях vs. бачення сенсу життя ( $N=1802$, кореспонденс аналіз. За даними моніторингу IC НАН Украӥни, 2019) 


\section{ЛІТЕРАТУРА}

1. Ловинк Г. Критическая теория интернета. - М.: Ад Маргинем Пресс, Музей современного искусства «Гараж», 2019. - 304 c.

5. Наумова М. Українці в соціальних медіа: популярні платформи та активності // Українське суспільство: моніторинг соціальних змін: зб. Наукових праць. Вип. 4(18) Київ: ІС НАН України, 2017. С. 400-413.

2. Active social media penetration in selected European countries in January 2019. Електронний документ. - Режим доступу: https://www.statista.com/statistics/295660/active-social-mediapenetration-in-european-countries/

3. Digital 2019: Ukraine. Електронний документ. - Режим доступу: https://datareportal.com/reports/digital-2019-ukraine

4. Соціальні мережі: хто використовує і як? Електронний документ. - Режим доступу: http://www.gemius.com.ua/vse-statidlja-chtenija/socialni-merezhi-xto-vikoristovuje-i-jak.html

6. Кин Дж. Демократия и декаданс медиа/ пер. с англ.. Кралечкина; под науч. Ред. А. Смирнова; Нац. исслед. УН-т «Высшая школа экономики». - М.: Изд. дом Высшей школы экономики, 2015. - $312 \mathrm{c}$.

7. Гринфилд А. Радикальные технологии: устройство повседневной жизни/ Гринфилд Адам; пер. с анг. И. Кушнарёвой. - М.: Изд. Дот «Дело» РАНХиГС, 2018. - 404 с.

\section{REFERENCES}

1. Lovink G. Critical Internet Theory.- M.: Ad Margin Press, Garage Museum of Modern Art, 2019. - 304 p. [In Russian]

4. Social networks: who uses and how? Access mode: http://www.gemius.com.ua/vse-stati-dlja-chtenija/socialnimerezhi-xto-vikoristovuje-i-jak.html_[In Ukrainian]

5. Naumova M. Ukrainian public media: popular platforms and activity. // Ukrainian society: monitoring of political changes:

collection. Scientific works. Vip. 4 (18) Kyiv: IS of the NAS of Ukraine, 2017. p. 400-413. [In Ukrainian]

6. Keane J. Democracy and Media Decadence. / Ed. A. Smirnova; Nat. research University "Higher School of Economics". - M., 2015. - 312 p. [In Russian].

7. Greenfield A. Radical technologies: the device of everyday life / Greenfield Adam; per. with eng. I. Kushnaryova. - M.: Publishing House "Delo",2018. - 404 p. [In Russian].

Types of social platforms' expansion in the Ukrainian landscape

M. Naumova

Abstract. Social networks have become today a central element in the design of the media space and the dominant way of experiencing everyday life. They are no longer only the dominant embodiment of modern internet culture, but fully represent the modern technological mode of social. Based on data from two monitoring studies in 2017 and 2019, the article examines the dynamics of Ukrainians' preferences regarding major social media platforms and activities. The material also presents the segmentation of social media users by preferences for their use, and the socio-demographic profile of each category of users.

Keywords: social media, social networking, on-line practices, user-generated content, digital network culture. 